\title{
REASSESSING DEVELOPMENT: ACHIEVING WOMEN'S ECONOMIC EMPOWERMENT WITH RURAL SOCIAL ENTREPRENEURSHIP
}

\author{
Kenesha Khurana \\ Modern School Barakhamba Road \\ DOI: 10.46609/IJSSER.2020.v05i07.025 URL: https://doi.org/10.46609/IJSSER.2020.v05i07.025
}

\begin{abstract}
Social entrepreneurship has become the new trend globally, as various countries recognize the need for a sustainable and inclusive approach to economic growth and corporate activity. Since the 1950s, the social entrepreneurship industry has grown massively in India as well, and the government has introduced several schemes to foster the same among those in low income backgrounds. Women in particular, have been able to transcend traditional gender roles and social boundaries to become social entrepreneurs, as statistics show they own more social enterprises than men. This model has a particular advantage to lift uneducated, rural women out of poverty and help them gain literacy and empower themselves. However, there is a need for more policy measures to meaningfully assist rural women as they are among the most vulnerable sections of Indian society. This paper will examine the current scenario with respect to social entrepreneurship among rural women, and suggest policy measures that will affect change in a manner that is culturally sensitive and truly integrates the communities of rural women into economic change and growth.
\end{abstract}

Keywords: Social entrepreneurship, Development, Economy, Women, Rural

\section{INTRODUCTION}

Womens' participation in the Indian labour force has displayed a worrying downward trend over the course of several decades. In 2017, India's female labor force participation rates (FLFPR) fell to its lowest level since Independence (Nikore, 2019). In particular, the participation of rural women has shown a sharp decline. Women, especially rural women, have largely been undertaking labor-intensive, home-based, and informal work, concentrated in low-productivity sectors (Nikore, 2019). The proportion of rural women working in agriculture fell from $88.1 \%$ in 1977-78 to $73.2 \%$ in 2017-18 (Nikore, 2019). Amongst rural women, the largest declines in 


\section{International Journal of Social Science and Economic Research}

ISSN: $2455-8834$

Volume: 05, Issue: 07 "July 2020"

FLFPR over the 1993 - 2018 period are in the below 34-year, child-bearing age categories (Nikore, 2019). The deep-rooted segregation of gender-specific activities further results in a lack of family support for women's careers and prevents Indian women from participating in the workforce (Nikore, 2019).

The economic empowerment of women is essential and indispensable for the larger growth of developing countries. Womens' empowerment and leadership is likely to lead to multiplier effects that ultimately leads to economic growth and empowerment. Women would be more likely to hire other women to assist in the running businesses, and creating other women beneficiaries (Siba, 2016). Further, women would be more likely to pass on any gains to family members, which increases opportunities for education and a rise in the household income. It is documented that when women control a greater proportion of household resources, more income is allocated towards food and childrens' education (Siba, 2016).

Social enterprise activity is a rapidly growing sector in India. A study by the British Council between 2015 and 2016 found that there may be close to 2 million social enterprises in India (British Council, 2016). In this growing space, it is crucial to evaluate the impact on rural women, as they are among the most vulnerable and face the most challenges with respect to lack of education and lack of access to opportunities for employment. Nearly 25 percent of social enterprises are led by women. As a contrast to the same, less than 9 percent of commercial small and medium enterprises in mainstream business and private sector firms are led by women (Salovaara \& Wade, 2018). Thus, it is clear that women have an important role in creating employment, growing businesses and generating economic growth.

This paper will examine and emphasize the need for the empowerment of rural women, with the social entrepreneurship model. The model has great potential to transform the lives of rural women both economically and socially. It is a key sector to harness to promote the cause of women participating in the labour force, and being seen as important economic contributors. The paper will examine existing schemes and theories regarding increasing rural womens' labour force participation. Then, it will evaluate the particular challenges that face developing countries and suggest policy recommendations to implement social entrepreneurship initiatives in rural areas, in a sustainable and culturally sensitive manner.

\section{BACKGROUND}

Social entrepreneurship began to take off as a concept in India in the 1950s, with the establishment of both the Land Gift Movement and the Amul Dairy Co-operative, which set the landscape for the future of social enterprises in India. The Land Gift movement saw the redistribution of over seven million acres of land to India's poor and landless. Amul became the 


\section{International Journal of Social Science and Economic Research}

ISSN: $2455-8834$

Volume: 05, Issue: 07 "July 2020"

first business model managed by low income dairy farmers. With the establishment of Ashoka in 1981, the term social entrepreneurship was formally introduced in India for the first time. Through the 1990s, several sustainable business models were set up such as SELCO Solar and Basix, which aimed to bring services and generate employment in low income households. The Companies Act, 2013 now has corporate social responsibility encoded into law, which is likely to encourage more initiatives of this kind. At present there are several incubators, accelerators, donor agencies and corporations which support social enterprises (British Council, 2016).

Therefore, in the Indian cultural context specifically, social entrepreneurship is targeted at creating sustainable business models that benefit the poor, and low income households. The government has over time implemented schemes particular to rural social entrepreneurship and SME empowerment. The Support to Training and Employment Programme for Women (STEP) program was launched by the Government of India's Ministry of Women and Child Development to train women with no access to formal skill training facilities, especially in rural India (Aranha, 2019; Goyal, 2011). The National Rural Livelihoods Mission (NRLM), a program under the Ministry of Rural Development (MoRD), which has organized about 56 million women into Self Help Groups (SHGs), thereby leveraging over $\$ 30$ billion in loans in the last five years (Kutty and Gupta, 2019). NRLM's focus on social and financial inclusion has provided an impetus to women entrepreneurs to invest in their businesses and contribute toward a financially stable future (Kutty and Gupta, 2019).

Recognizing the growing need for business advisory support and access to affordable and timely finance, the Government of India, along with the World Bank, is implementing a \$500 million investment through the National Rural Economic Transformation Project (NRETP) (Kutty and Gupta, 2019).

The project recently coordinated with the United Nations Development Program and other stakeholders such as impact investors, social enterprises, fintech firms, e-commerce players, and incubators at a consultation on rural enterprise development (Kutty and Gupta, 2019). With initiatives such as these in the offing, the growth of transformative women-led enterprises in rural India has begun (Kutty and Gupta, 2019).

However, a survey of schemes for social entrepreneurship of rural women shows that there is still much room for improvement to address the root causes of their lack of work force participation. Rural women and those from low income areas often do not possess the literacy, or autonomy in the household to be making financial decisions. This greatly increases the risk of them being exploited, even if they were to receive the money. A study in the north east showed that women from low income areas still finance through their own sources without the resources 


\section{International Journal of Social Science and Economic Research}

ISSN: $2455-8834$

Volume: 05, Issue: 07 "July 2020"

to access government schemes or banks. (Sinha, 2003) It is further pertinent to note that the proportion of women entrepreneurs differs depending on the region of the country. The highest proportion of female-led social enterprises is in South India $(35 \%)$, followed by North India $(31 \%)$ and West India (23\%), whereas it is much lower in East India (8\%) and North-East India (3\%) (British Council, 2016). Therefore, from a policy perspective, it is imperative for the government to assess the differing conditions in various regions of the country, and assess how to assist women entrepreneurs according to the specific context of the region.

\section{DISCUSSION}

In order to effectively tackle problems specific to rural women, policy measures must take into account the unique challenges of developing countries and rural regions, and specific microcosmic challenges. This means that there cannot be a one size fits all approach or simply importing social entrepreneurship models for developed nations, which are often tailored to Eurocentric notions of development (Kummitha, 2016). Given the diversity and varied cultural contexts in India, social enterprise must be introduced to rural women in such a way that it is sensitive to their needs for any meaningful change.

To this end, there is a need to be aware of Eurocentric methods and challenge them. Surveys have found that it is desirable when social enterprises make sure that they employ people from certain local communities (Kummitha, 2016). This helps them to connect with these communities and facilitates the trust-building processes. Employees who come from local communities know the local culture, language and customs, making it easier for social enterprises to connect with the communities (Kummitha, 2016). This aspect especially contributes to the sustainable social orientation of social enterprises concerned and helps them to enhance processes of trust building and social value creation (Kummitha, 2016). In general, there is a need for more literature on social entrepreneurship in the South Asian context to develop region specific models. To do so, it is key to facilitate networking between gender-focused social enterprises and women's organisations nationally and internationally with a view to sharing best practice and replicating successful models (British Council, 2017).

Further, adopting a purely Eurocentric approach of leaving the issue of social entrepreneurship to private entities ignores the fact that in a society like India, even entities also carry with them historically gendered connotations (Salovaara and Wade, 2018). The non-profit sector has been considered a more 'feminized' domain as women are not expected to be the primary providers for their households (Salovaara and Wade, 2018). As mentioned in the previous section of this paper, self-help groups (SHGs) are a very common model that is used in this sphere, mostly in collaboration with Western entities or global entities like the World Bank (British Council, 


\section{International Journal of Social Science and Economic Research}

ISSN: $2455-8834$

Volume: 05, Issue: 07 "July 2020"

2017). However, they once again are often ignorant of the cultural context of rural India. SHGs are not formal social enterprises, but they are among the most common model for a combination of income generation and community improvement activities in India (British Council, 2017). Income generation is often combined with skill development. Although women are given leadership roles within Self-Help Groups, they do not necessarily have full control over the system (British Council, 2017). The extent to which women will be able to engage in these activities depends on their ability to negotiate with their family. Many of the NGOs that facilitate these activities are led by men (British Council, 2017).

Rural social entrepreneurship can also be used as a valuable tool for social and cultural development, underlining the importance of promoting indigenous and culturally sensitive models. For example, Jaipur Rugs promote traditional crafts, textiles, and handmade products by creating market links for rural artisans through fair trade principles (British Council, 2017). DesiCrew provide skills training and jobs in call centres (British Council, 2017). Creating a women's social enterprise network to increase the peer support available specifically for women social entrepreneurs and board members. This will help women social entrepreneurs share best practice, provide mentorship, and discuss the unique challenges of social enterprise (British Council, 2017). This will also help to further foster cultural innovation and a preservation of indigenous traditions.

\section{CONCLUSION}

Social enterprises offer a way for more women in rural areas to contribute to the country's growth and provide innovative, sustainable solutions to its long entrenched social problems (Khanna, 2015). Policy measures in the future must focus on fostering social entrepreneurship in a sustainable fashion, and be tailored to the particular needs of rural Indian women. This will require particular attention to the integration of the local community in infrastructural changes.

Training programs for women to start their own businesses and become entrepreneurs, as well as brief them on the latest developments in industry and technology is another manner in which policy can aid women in their ventures. Creation of nodal centers with gender sensitized staff would assist women who lack awareness of these policies to then learn about them and subsequently avail of them (Goyal, 2011).

In order to ensure equal access to funding for rural women, policies must be enacted for women to receive grants and loans in smaller denominations, with lesser bureaucratic red tape and documentation. This effectively propels the growth of smaller scare organizations. NGOs such as PRADAN carry out savings led microfinancing activities for women from low income areas, 


\section{International Journal of Social Science and Economic Research}

ISSN: $2455-8834$

Volume: 05, Issue: 07 "July 2020"

stressing on group savings as a means of strengthening womens' financial management skills (Goyal, 2011).

Combining financial empowerment and market integration in the social enterprise model must be coupled with conducting awareness programs to change ingrained mindsets, for there to be long term change in this sphere (Salovaara \& Wade, 2018). An additional policy recommendation is to move from an approach that focuses on growing individual enterprises to one that creates networks of women-led businesses. This will help rural women address the unique challenges they face, such as restrictions on womens' mobility, the sectors in which they feel they may be able to start a business in an easier fashion, and domestic work that they are still expected to perform (Salovaara \& Wade, 2018).

Therefore, it would be far more beneficial to women entrepreneurs in rural and low income areas, if government grants and investment funding were not tied to scalability of individual organizations, but instead on a more collective approach that focuses on expanding a larger number in the community of women entrepreneurs. Such knowledge sharing would also have significantly more positive effects in the long term and can serve the needs of a more diverse set of women, who will serve as resources not only for their own enterprises but for each other (Salovaara \& Wade, 2018).

\section{REFERENCES}

Aranha, J. 'Attention, Women Entrepreneurs! 8 Govt Schemes You Should Be Aware Of', June 10, 2019, The Better India, available at:https://www.thebetterindia.com/185591/womenentrepreneurs-govt-scheme-business-loans-benefits-india/

British Council, (2017), "Activist to Entrepreneur: The role of social enterprise in supporting women's empowerment in India”, Retrieved from https://www.britishcouncil.org/sites/default/files/british council social enterprise wome ns_empowerment_in_india_web_final.pdf

British Council, 'Social value economy A Survey of the Social Enterprise Landscape in India', December 2016

Goyal, M. 'Women entrepreneurship in india-problems and prospects', International Journal of Multidisciplinary Research, Vol.1 Issue 5, September 2011 
International Journal of Social Science and Economic Research

ISSN: 2455-8834

Volume: 05, Issue: 07 "July 2020"

Khanna, A., (2015), "Women social entrepreneurs are driving transformation", Livemint, Retrieved from https://www.livemint.com/Opinion/13vonjOSaE4XrJdxyDgn1J/Womensocial-entrepreneurs-are-driving-transformation.html

Kummitha, R., (2016), "Social Entrepreneurship As A Tool To Remedy Social Exclusion: A Win-Win Scenario?", South Asia Research, Vol. 36 Issue 1, pp 1-19.

Kutty, B.M, and Gupta, A., (2019), “The rise of India's rural women entrepreneurs", World Bank Blogs, World Bank.org.

Nikore, M., (2019), "Where are India's working women? The fall and fall of India's female labour participation rate", London School of Economics South Asia Blog, Retrieved from https://blogs.lse.ac.uk/southasia/2019/10/22/where-are-indias-working-women-the-falland-fall-of-indias-female-labour-participation-rate/

Salovaara, I., Wade, J., 'How to Support Women Social Entrepreneurs in India', Stanford Social Innovation Review, March. 14, 2018

Salovaara, I., Wade, J., 'Women, Prosperity, and Social Change in India', Stanford Social Innovation Review, Feb. 14, 2018

Siba, E, 'Enabling Female Entrepreneurs and Beyond', Brookings, July 25, 2016

Sinha, N. 'Women Entrepreneurship in the North East India: Motivation, Social Support and Constraints', Indian Journal of Industrial Relations, Vol. 38, No. 4 (Apr., 2003), pp. 425443 